\title{
Identification of Immunostimulatory Dendritic Cells in the Synovial Effusions of Patients with Rheumatoid Arthritis
}

\author{
Nathan J. Zvaifler, Ralph M. Steinman, Gilla Kaplan, Lisa L. Lau, and Marcos Rivelis \\ Division of Rheumatic Diseases, Department of Medicine, University of California Medical Center, San Diego, California 92103; \\ and The Rockefeller University and The Irvington House Institute, New York, New York 10221
}

\begin{abstract}
Dendritic cells in the circulation are leukocytes that are rich in Ia antigens and that actively stimulate $T$ cell replication. We have identified dendritic cells in the joint effusions of patients with rheumatoid arthritis. By phase-contrast and immunofluorescence microscopy, synovial mononuclear cells contained 1-5\% dendritic profiles that were rich in HLA-DR and DQ, had small amounts of $\mathrm{C} 3$ bi receptor, and lacked a battery of monocyte and lymphocyte markers. These dendritic cells could be enriched to $60-80 \%$ purity by cytolytic depletion of monocytes and lymphocytes with a group of monoclonal antibodies (MAb) and complement. By transmission electron microscopy, the dendritic cell processes were bulbous in shape and lacked organelles. The cytoplasm had few lysosomes or endocytic vacuoles but contained a well-developed smooth reticulum that was comparable to that previously described in the Ia-rich interdigitating cells of lymphoid tissues. The growth of sodium periodate-modified $T$ lymphocytes was used as a rapid quantitative assay of accessory cell function. Synovial mononuclear cells were some ten times more active than normal blood cells. Treatment with $\alpha$-Ia MAb and complement ablated stimulatory function. In contrast, removal of monocytes (MAb, 3C10) or monocytes and B (MAb, BA-1) plus T (MAb, OKT3, or T101) lymphocytes did not significantly alter total activity, and the function per viable cell increased four- to eightfold. We conclude that rheumatoid arthritis synovial fluids contain cells that are comparable in function, phenotype, and structure to blood dendritic cells, although the frequency (1-5\%) is 10 times greater in joints. The reason for their accumulation in the articular cavity is not known, but dendritic cells may be important in perpetuating the joint inflammation characteristic of this disease.
\end{abstract}

\section{Introduction}

The process that initiates rheumatoid arthritis (RA) ${ }^{1}$ is unknown, but its perpetuation appears to depend on immunologically mediated events (1). Immune competent cells and

Address reprint requests to Dr. Zvaifler, Division of Rheumatic Diseases, Department of Medicine, University of California Medical Center, San Diego, CA 92103.

Received for publication 31 January 1985

1. Abbreviations used in this paper: C, complement; DC, dendritic cell; FCS, fetal calf serum; MAb, monoclonal antibody; MLR, mixed leukocyte reaction; RA, rheumatoid arthritis.

J. Clin. Invest.

(C) The American Society for Clinical Investigation, Inc.

0021-9738/85/08/0789/12 $\$ 1.00$

Volume 76, August 1985, 789-800 their products are abundant in the membrane lining the joint and in the synovial fluid. A majority are polymorphonuclear cells, but $15-20 \%$ are mononuclear. Of these, $T$ cells predominate. They differ from blood $T$ lymphocytes in that the majority are $\mathrm{T}^{+}$and show many features of activation including surface Ia antigens (2-5). Rheumatoid effusions also contain unusual cytotoxic cells that lack Fc receptors and other markers of conventional natural killer or cytotoxic $\mathrm{T}$ lymphocytes. These cytotoxic cells appear to be derived from activated joint $T$ cells $(6,7)$. Somewhat surprising, in view of their activated status, is the finding that RA synovial fluid $T$ cells respond poorly to lectins and autologous or allogeneic cells (8-13). Synovial non-T cells on the other hand are potent stimulators in the mixed leukocyte reaction (MLR) and usually cause several times more proliferation of autologous blood $T$ lymphocytes than do blood non-T cells (13-15).

A distinctive leukocyte, the dendritic cell (DC), seems to be the principal stimulator of resting $T$ lymphocytes as in the MLR and oxidative mitogenesis, the proliferation of periodatemodified $T$ cells (16-20). DC were described originally in mice on the basis of novel cytologic features (21). The cells are nonphagocytic and lack several surface markers of macrophages, $T$ and $B$ lymphocytes, but they display large amounts of surface Ia and class I antigens that would contribute to their efficacy as stimulator cells (22-25). In several tissues and species, accessory function is diminished by procedures that deplete DC and are increased by methods that enrich for DC (16-20). These observations have been confirmed in mice with a specific $\alpha$-DC monoclonal antibody (MAb; 16, 17, 26). Unfortunately, such an antibody does not exist for the human DC. Examination of their role as accessory cells has required the specific elimination of other cell types. In the past, when this has been done, the results have been compatible with the data in mice; namely, depletion of monocytes or lymphocytes with specific MAb and complement $\left(C^{\prime}\right)$ produces no loss in stimulatory capacity for several $\mathrm{T}$ cell proliferative responses (19).

As noted above, the non-T cell fraction of RA synovial effusions are strong stimulators of MLR's. Thus, it is reasonable to look for DC in RA exudates. An added stimulus for these investigations is the knowledge that the RA joint lining contains Ia-rich cells (26-30), and some assume a stellate appearance in tissue culture (31-33). By using techniques developed for the study of human blood DC $(23,24)$, we have shown that RA effusions contain relatively large numbers of cells that are similar to blood DC in morphology, phenotype, and accessory function. These exudate DC are probably distinct from the stellate cells derived from RA synovial membrane.

\section{Methods}

Subjects. Patients having RA met the American Rheumatism Association criteria for classical RA (34). All but one was receiving treatment 
at the time of study; the majority were on disease modifying agents (gold, penicillamine, chloroquine) and the remainder on corticosteroids or nonsteroidal antiinflammatory agents. One patient (J.H.) had an asymmetric, oligoarticular, seronegative, large-joint arthritis associated with psoriasis. All patients and controls provided blood and/or joint samples with informed consent.

Culture medium, serum. The complete medium was RPMI 1640 (Gibco Laboratories, Grand Island, NY) supplemented with $1 \mathrm{mM}$ glutamine, $5 \times 10^{-5}$ 2-mercaptoethanol, $100 \mathrm{U} / \mathrm{ml}$ penicillin, $20 \mu \mathrm{g} /$ $\mathrm{ml}$ gentamicin, and 5-10\% fetal calf serum (FCS; HyClone Laboratories, Sterile Systems, Logan, UT, $\left.56^{\circ} \mathrm{C}, 30 \mathrm{~min}\right)$. Human serum was prepared from $1 \mathrm{U}$ of whole $\mathrm{AB}^{+}$blood with no additives (Greater New York Blood Center) after $4 \mathrm{~h}$ of clotting at $4^{\circ} \mathrm{C}$, clarification by centrifugation, and storage at $-70^{\circ} \mathrm{C}$.

Synovial fluid mononuclear cells. Synovial fluid was obtained by aseptic joint aspiration into sterile heparinized tubes or syringes $(10$ $\mathrm{U} / \mathrm{ml}$ ) and allowed to stand at room temperature for 30-60 min. A few samples were treated with $1.5 \mathrm{U} / \mathrm{ml}$ hyaluronidase (Wydase; Wyeth Laboratories, Marietta, PA) for $30 \mathrm{~min}$ at $37^{\circ} \mathrm{C}$ to reduce viscosity. In previous experiments, hyaluronidase did not influence stimulatory capacity for the autologous MLR (8). Mononuclear cells were isolated on Ficoll-Hypaque columns, washed three times in RPMI plus $10 \%$ FCS, and cultured on 100-mm plastic petri dishes (Falcon Labware, Becton, Dickinson \& Co., Oxnard, CA) in complete medium (above) with $5 \%$ FCS $\left(5-20 \times 10^{6}\right.$ cells/dish). In studies of adherence properties, mononuclear cells were plated for $1-3 \mathrm{~h}$ at $37^{\circ} \mathrm{C}$, and the nonadherent cells were dislodged by swirling and several washes. The adherent cells constituted $10-70 \%$ of the total and could be removed by vigorous pipetting with cold RPMI 1640 . When the entire synovial mononuclear population was cultured overnight, $>80 \%$ of the cells detached, and the remainder could be removed with vigorous pipetting. These were designated as overnight or day 1 nonadherent and adherent populations, respectively. Since adherence did not prove to be useful in enriching for synovial accessory function (see Results), we generally combined the cultured adherent and nonadherent fractions before further study.

Blood mononuclear cells. Heparinized blood was taken from normal volunteers or was purchased as buffy coats from the Greater New York Blood Center. Mononuclear cells were separated on FicollHypaque columns, and adherent cells were selected after 1-3 h of culture $\left(5 \times 10^{6}\right.$ cells $/ 100$-mm plastic petri dishes $)$ in complete medium with $5 \%$ FCS. Adherent cells typically represented $20-40 \%$ of the total and were comprised of $50-70 \%$ monocytes, $20-40 \%$ B cells, $10-20 \%$ $T$ cells, and $1-4 \%$ DC. After overnight culture, $60-80 \%$ of the adherent cells detached, and these were used as an active stimulator population (23).

Phagocytosis of latex particles. Latex particles $(1.1 \mu \mathrm{m}$, Dow Chemical Co., Indianapolis, IN) were used to detect phagocytosis at a cell/particle ratio of 1:100. $2 \times 10^{6}$ synovial fluid cells that were isolated from fresh effusions were mixed with opsonized latex $(40 \%$ AB serum, $1 \mathrm{~h}, 4^{\circ} \mathrm{C}$ ) in $2 \mathrm{ml} \mathrm{10 \%} \mathrm{FCS} \mathrm{RPMI} 1640$. The cells and particles were centrifuged $\left(400 \mathrm{~g}, 5 \mathrm{~min}, 20^{\circ} \mathrm{C}\right)$ to facilitate contact, and phagocytosis was allowed to occur for $1 \mathrm{~h}$ at $37^{\circ} \mathrm{C}$. Free latex was removed by washing the mixture twice with RPMI 1640 at $200 \mathrm{~g}, 5$ min each time. Cells were then attached to poly-L-lysine coated multiwell slides and examined by phase-contrast and immunofluorescence microscopy as described below.

$T$ cell proliferation assays. Graded doses of viable, irradiated $(3,000$ rads, ${ }^{137} \mathrm{Cs}$ ) stimulator cells were added to $1.5 \times 10^{5}$ periodate-modified $T$ cells (oxidative mitogenesis) in 6-mm flat wells (No. 3596; Costar, Data Packaging Corp., Cambridge, MA) in medium with $10 \%$ human $\mathrm{AB}^{+}$serum. $\mathrm{T}$ cells were nylon wool nonadherent blood mononuclears that were treated with $\alpha$-monocyte $(3 \mathrm{C} 10)$ and $\alpha$-Ia $(9.3 \mathrm{~F} 10) \mathrm{MAb}$ and $\mathrm{C}^{\prime}$ as described (24). T cells were either unrelated or syngeneic to the donor, and were modified with $1.2 \mathrm{mM}$ sodium periodate in phosphatebuffered saline (PBS) for $15 \mathrm{~min}$ on ice, spun at $900 \mathrm{rpm}$ for $10 \mathrm{~min}$ at $4^{\circ} \mathrm{C}$, and washed once in RPMI $\left.1640 .{ }^{3} \mathrm{H}\right]$ Thymidine uptake was measured at 48-64 h $(4 \mu \mathrm{Ci} / \mathrm{ml})$ and data displayed as mean counts per minute of triplicates \pm SEM. Controls were $<1,000 \mathrm{cpm}$ and included nonperiodate-modified $T$ cells cultured with stimulators, periodate $T$ cells without stimulators, and stimulators only.

Treatment with MAb and $C^{\prime}$. Equal volumes of cells and MAb were kept on ice for $20-40 \mathrm{~min}$. Another volume of rabbit $C$ was added and the mixture incubated $45-60 \mathrm{~min}$ at $37^{\circ} \mathrm{C}$. All reagents were diluted in RPMI, $0.3 \%$ bovine serum albumin, $25 \mathrm{mM}$ Hepes buffer, and $10 \mu \mathrm{g} / \mathrm{ml}$ deoxyribonuclease (type I; Sigma Chemical Co., St. Louis, MO). The final concentrations were $1.6-2.5 \times 10^{6} / \mathrm{ml}$ for cells, $1-10 \mu \mathrm{g} / \mathrm{ml}$ for MAb, and 1:9 for rabbit serum reconstituted from lyophilized samples from selected rabbits. After treatment, the cells were washed three times and used in oxidative mitogenesis assays. The depletion of specific subsets of leukocytes was monitored by immunofluorescence with alternative MAb to that subset (see Table I). For monocytes, we used 63D3; for B cells 1F5; and for T cells, OKT3 or T11. Monocyte depletion was also apparent by cytologic criteria.

Immunofluorescence. All reagents were diluted in RPMI with 5\% horse serum (Gibco Laboratories) and $0.02 \%$ sodium azide. MAb were obtained from commercial sources and/or have been described elsewhere (Table I). $3 \times 10^{4}$ cells in $20 \mu \mathrm{i}$ RPMI were attached at $4^{\circ} \mathrm{C}$ to polyL-lysine coated multiwell slides (24). The cells were then exposed on ice to MAb for $60 \mathrm{~min}$, rinsed in PBS, exposed to biotinyl horse $\alpha$-mouse IgG (Vector Laboratories, Burlingame, CA) at $50 \mu \mathrm{g} / \mathrm{ml}$ for $30 \mathrm{~min}$, overlaid with fluorescein avidin (Vector Laboratories) at 100 $\mu \mathrm{g} / \mathrm{ml}$ for $30 \mathrm{~min}$, rinsed, fixed in $10 \%$ formalin/PBS for $20 \mathrm{~min}$, mounted in glycerol, and viewed by phase-contrast and fluorescence microscopy. This technique allowed us to evaluate staining with a large number of MAb using only small numbers of cells. DC prepared in this manner displayed an irregular cell shape but the cytologic detail and extent of spreading on multiwell slides, processed for fluorescence microscopy, was less clear than that described previously for glass coverslips $(19,23)$.

Transmission electron microscopy. Cells were washed, fixed in a fresh mixture of $2.5 \%$ glutaraldehyde (Polysciences Inc., Warrington, PA) in $0.1 \mathrm{M}$ sodium cacodylate buffer (pH 7.4) containing $0.1 \mathrm{M}$ sucrose, rinsed in saline, and then postfixed with $1 \%$ osmium tetroxide. Samples were stained with $0.25 \%$ uranyl acetate, dehydrated in graded alcohols, and embedded in Epon. Two populations of synovial mononuclear cells were examined: control cells, which were exposed to complement only or left untreated; and DC, which were enriched by monocyte and lymphocyte elimination as described in Results.

\section{Results}

Synovial fluid mononuclear cells stimulate the oxidative mitogenesis of $T$ cells. Evidence that synovial effusions contained DC came first from assays of accessory or stimulator function. The assay was the oxidative mitogenesis or proliferation of $T$ lymphocytes modified with sodium periodate $(36,37)$. When $T$ cell surface carbohydrates are oxidized to form aldehydes, the lymphocytes will proliferate actively upon addition of accessory cells, particularly DC (17-19). This system has the additional advantages that no distinction is made between allogeneic and syngeneic stimulators and maximal proliferation occurs at $\sim 72 \mathrm{~h}$.

In the initial experiments, unfractionated RA synovial fluid mononuclear cells were compared with normal adherent blood populations. RA cells were at least threefold better as stimulators of oxidative mitogenesis (Table II), regardless of the type of therapy the patients were taking. Since adherent cells represent $1 / 3$ of total blood mononuclears but have the bulk (60-90\%) of the accessory activity (19), we conclude that synovial exudate mononuclears are some 10 times better as stimulators than 
Table I. Monoclonal Mouse Anti-human Leukocyte Antibodies

\begin{tabular}{|c|c|c|c|c|}
\hline Name & Ig subclass & Source & Polypeptide & Specificity \\
\hline & & & $m o l w t$ & \\
\hline $9.3 \mathrm{~F} 10$ & $\operatorname{IgG}_{2 \mathrm{a}}$ & Van Voorhis (24) & $34 / 29,000$ & HLA-DR \& DQ" \\
\hline OKIa & $\operatorname{IgG}_{2}$ & $\begin{array}{l}\text { Ortho Diagnostic Systems, Inc., Johnson \& } \\
\text { Johnson, Raritan, NJ }\end{array}$ & $34 / 29,000$ & HLA-DR \\
\hline Leu-10 & $\operatorname{IgG}_{1}$ & Ortho Diagnostic Systems, Inc. & $32 / 29,000$ & HLA-DQ \\
\hline OKM1 & $\mathrm{IgG}_{2 \mathrm{~b}}$ & Ortho Diagnostic Systems, Inc. & 170,000 & C3bi receptor \\
\hline 63D3 & $\operatorname{IgG}_{1}$ & $\begin{array}{l}\text { Bethesda Research Laboratories, } \\
\text { Gaithersburg, MD }\end{array}$ & 200,000 & Monocytes \\
\hline $3 \mathrm{C} 10$ & $\mathrm{IgG}_{2 \mathrm{~b}}$ & Van Voorhis (24) & 55,000 & Monocytes \\
\hline $3 G 8$ & $\operatorname{IgG}_{1}$ & Fleit (51) & $48-60,000$ & Fc receptor \\
\hline T101 & $\operatorname{lgG}_{2 a}$ & Hybritech Inc., La Jolla, CA & 65,000 & T cells \\
\hline OKT3 & $\mathrm{IgG}_{\mathbf{a}}$ & Ortho Diagnostic Systems, Inc. & 19,000 & $T$ cells \\
\hline 1F5 & $\operatorname{IgG}_{2 a}$ & Clark (50) & 35,000 & B cells \\
\hline BA-1 & $\operatorname{lgM}$ & Hybritech Inc. & NA§ & B \& granulocytes \\
\hline OKT6 & $\operatorname{IgG}_{1}$ & Ortho Diagnostic Systems, Inc. & 52,000 & Thymocytes, Langerhans cells \\
\hline Leu-7 (HNK1) & IgM & Becton-Dickinson \& Co., Oxnard, CA & 110,000 & NK cells \\
\hline HL & $\operatorname{IgG}_{1}$ & Posnett (35) & $52-63,000$ & $\begin{array}{l}\text { Hairy cell leukemia } \\
\text { activated B cells }\end{array}$ \\
\hline $8 \mathrm{C} 4^{*}$ & IgM & Dr. Steinman, The Rockefeller University & NA & ?HLA-DQ \\
\hline 4B2 $\ddagger$ & IgG & Dr. Steinman, The Rockefeller University & 200,000 & Leukocyte antigen \\
\hline
\end{tabular}

* 8C4 is a new MAb that reacts primarily with DC and B cells in blood and tonsil suspensions and with interdigitating cells and B cells in lymphoid tissue sections. $¥ 4 \mathrm{~B} 2$ reacts with all blood and joint leukocytes but not platelets, fibroblasts, endothelium, and several epithelia (unpublished). $\S \mathrm{NA}$, not available. "Recent studies (unpublished) indicate that 9.3F10 identifies an epitope found on both DR and DQ.

unfractionated blood mononuclears. However, periodate-treated $T$ cells from RA and normal individuals responded similarly to autologous or allogeneic blood stimulators (data not shown).

The adherence properties of the synovial stimulators were evaluated at varying times in culture. The specific activity of freshly prepared, adherent populations was greater than the nonadherent fraction, but a substantial ( $50 \%$ or more) amount of the total activity was nonadherent. At subsequent time

Table II. A Comparison of Synovial and Blood Cells as Stimulators of Oxidative Mitogenesis

\begin{tabular}{|c|c|c|c|c|c|c|c|c|c|}
\hline \multirow[b]{3}{*}{ Experiment } & \multirow[b]{3}{*}{ Test day } & \multicolumn{8}{|c|}{ Proliferation to graded doses of stimulators } \\
\hline & & \multicolumn{4}{|c|}{ Synovial cells $\left(\times 10^{-4}\right)$} & \multicolumn{4}{|c|}{ Blood cells $\left(\times 10^{-4}\right)$} \\
\hline & & 5.0 & 1.6 & 0.5 & 0.16 & 5.0 & 1.6 & 0.5 & 0.16 \\
\hline & & \multicolumn{4}{|c|}{$\operatorname{cpm}\left[{ }^{3} H\right] T d R \times 10^{-3}$} & \multicolumn{4}{|c|}{$c p m\left[{ }^{3} H\right] T d R \times 10^{-3}$} \\
\hline 1 & 0 & 19.0 & 12.0 & 7.3 & 2.2 & 9.2 & 3.8 & 1.6 & - \\
\hline 2 & 1 & 78.2 & 61.9 & 43.3 & 22.5 & 57.2 & 28.9 & 16.4 & 4.2 \\
\hline 3 & 2 & 36.8 & 22.8 & 12.0 & 2.9 & 22.1 & 9.9 & 3.2 & - \\
\hline 4 & 1 & 57.5 & 38.4 & 21.3 & 4.8 & 47.5 & 25.6 & 9.7 & 1.8 \\
\hline
\end{tabular}

$1.5 \times 10^{5}$ periodate-treated cells were cultured with graded doses of irradiated unfractionated mononuclear cells, derived from synovial fluid after 0,1 , or $2 \mathrm{~d}$ of culture, or plastic adherent blood cells also used after $0-2 \mathrm{~d}$ of culture. The $\mathrm{T}$ cells were autologous to the blood non- $\mathrm{T}$ cells and allogeneic to the synovial cells in experiments 1,2 , and 4 . In experiment 3 , both of the stimulator populations were allogeneic to the periodate $T$ cells. 
Table III. Accessory Function of Adherent or Nonadherent Synovial Fluid Cells after Various Times in Culture

\begin{tabular}{|c|c|c|c|c|c|c|}
\hline \multicolumn{3}{|c|}{ Synovial fluid stimulator cells } & \multicolumn{4}{|c|}{$\begin{array}{l}\text { Proliferation to graded doses of } \\
\text { stimulators } \times 10^{-4}\end{array}$} \\
\hline \multirow[t]{2}{*}{ Patient } & $\begin{array}{l}\text { Test } \\
\text { day }\end{array}$ & Fraction & 5.0 & 1.6 & 0.5 & 0.16 \\
\hline & & & \multicolumn{4}{|c|}{$c p m^{3} H-T d R \times 10^{-3}$} \\
\hline \multirow{3}{*}{$\begin{array}{r}\text { F.McG. } \\
\text { (RA) }\end{array}$} & 0 & Total & 27.2 & 10.8 & 2.6 & 1.8 \\
\hline & 0 & Adherent & 46.1 & 34.9 & 12.6 & 2.5 \\
\hline & 0 & Nonadherent & 11.6 & 3.6 & 2.6 & 1.5 \\
\hline \multirow[t]{2}{*}{ A.P. (RA) } & 0 & Adherent & 13.5 & 3.7 & 1.2 & - \\
\hline & 0 & Nonadherent & 7.5 & 4.6 & 1.6 & 1.2 \\
\hline \multirow[t]{2}{*}{ J.H. (PSA) } & 1 & Adherent & 31.6 & 27.3 & 8.4 & - \\
\hline & 1 & Nonadherent & 21.0 & 10.5 & 1.1 & - \\
\hline \multirow{2}{*}{$\begin{array}{l}\text { M.R. No. } 1 \\
\text { (RA) }\end{array}$} & 1 & Adherent & 58.8 & 39.4 & 13.9 & 5.4 \\
\hline & 1 & Nonadherent & 44.9 & 27.5 & 11.4 & 3.3 \\
\hline \multirow{2}{*}{$\begin{array}{l}\text { W.R. No. } 2 \\
\text { (RA) }\end{array}$} & 1 & Adherent & 68.0 & 50.6 & 30.9 & 7.4 \\
\hline & 1 & Nonadherent & 78.4 & 48.9 & 22.4 & 7.0 \\
\hline \multirow{2}{*}{$\begin{array}{l}\text { F.McG. } \\
\text { (RA) }\end{array}$} & 2 & Adherent & 41.1 & 24.9 & 11.5 & 6.9 \\
\hline & 2 & Nonadherent & 52.5 & 39.3 & 24.9 & 12.9 \\
\hline
\end{tabular}

The preparation of adherent and nonadherent stimulator cells is described in Methods. PSA, psoriatic arthritis.

points (1-2 d), stimulating activity was again found in both plastic adherent and nonadherent fractions (Table III). With time in culture, the specific activity increased in the nonadherent fraction, but the total activity was not significantly altered (e.g., patient F.McG., Table III).

Cell surface markers of the stimulator cell in rheumatoid effusions. To test if the stimulator in RA effusions expressed surface antigens that were comparable to blood DC, stimulatory activity was studied after treating synovial cells with $\mathrm{MAb}$ and rabbit $\mathrm{C}^{\prime}$. Mononuclear counts were reduced $<10 \%$ by $\mathrm{C}^{\prime}$ alone (10 experiments); $32 \pm 17 \%$ with the monocyte specific $\mathrm{MAb}$

Table IV. Accessory Function of Monocyte-depleted Synovial Fluid Mononuclear Cells

\begin{tabular}{|c|c|c|c|c|c|c|c|}
\hline \multicolumn{3}{|c|}{ Synovial fluid stimulator cells } & \multicolumn{5}{|c|}{$\begin{array}{l}\text { Proliferation to graded doses of } \\
\text { stimulators }\left(\times 10^{-4}\right)\end{array}$} \\
\hline \multirow[t]{2}{*}{ Patient } & Knee & Treatment & 5.0 & 1.6 & 0.5 & 0.16 & 0.05 \\
\hline & & & \multicolumn{5}{|c|}{$c p m^{3} H-T d R \times 10^{-3}$} \\
\hline \multirow[t]{4}{*}{ J.K. (RA) } & Left & $3 \mathrm{C} 10 / \mathrm{C}^{\prime}$ & - & 52.5 & 38.2 & 27.4 & 13.0 \\
\hline & & $3 \mathrm{C} 10 /$ no $C^{\prime}$ & 79.1 & 58.2 & 27.5 & 11.5 & - \\
\hline & Right & $3 \mathrm{C} 10 / \mathrm{C}^{\prime}$ & 48.1 & 21.0 & 17.4 & 5.8 & 2.4 \\
\hline & & $3 \mathrm{C} 10 /$ no $\mathrm{C}^{\prime}$ & 37.3 & 17.8 & 5.7 & 1.6 & - \\
\hline
\end{tabular}

$1.5 \times 10^{5}$ allogeneic periodate-treated $\mathrm{T}$ cells were stimulated with graded doses of irradiated synovial fluid mononuclear cells from each knee of a patient with RA. Adherent synovial fluid cells were cultured overnight and treated with $3 \mathrm{C10} \alpha$-monocyte MAb $\pm \mathrm{C}^{\prime}$ before use. The extent of kill in the presence of $\mathrm{C}^{\prime}$ was 24 and $40 \%$ in the left and right knees, respectively.

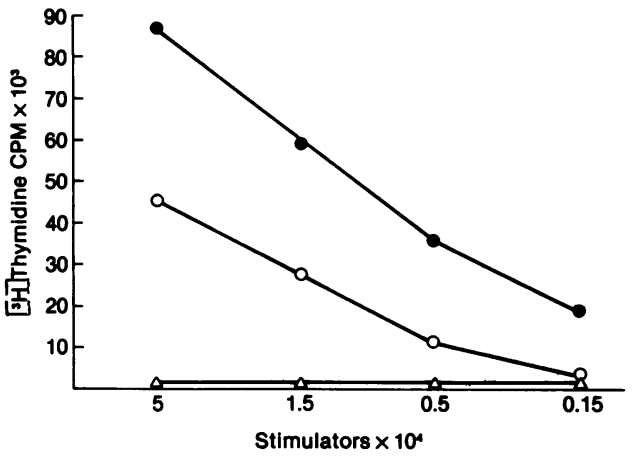

Figure 1. Stimulating activity of different synovial fluid populations for oxidative mitogenesis. Nonadherent RA cells, after overnight culture, were treated with $\mathrm{C}$ alone (o; $16 \%$ cell death), $3 \mathrm{C10} \alpha$ monocyte MAb (๑; 53\% cell death) or with 9.3F10 $\alpha$-Ia MAb ( $\Delta$; $48 \%$ cell death).

$3 \mathrm{C} 10$ plus $\mathrm{C}^{\prime}$ (6 experiments); and $85-95 \%$ (12 experiments) with a "cocktail" of MAb to T cells (T101 or OKT3), B cells (BA-1 or 1F5), and monocytes (3C10). The efficiency of cell depletion was always $<90 \%$ and was verified by immunofluorescence with additional MAb.

The effusions from both knees of a patient with RA were studied (Table IV). Monocyte elimination did not reduce total stimulatory capacity, and the specific activity of the surviving cells was increased threefold. Of interest was the finding that cells from the left knee, which was more inflamed than the right (synovial fluid leukocyte counts of $27,500 / \mathrm{mm}^{3}$ and $13,800 / \mathrm{mm}^{3}$, respectively), were more stimulatory. In a second patient (Fig. 1), elimination of cells bearing class II or Ia antigens completely abrogated stimulating activity. In contrast, cells surviving $3 \mathrm{C} 10$ and $\mathrm{C}$ retained activity and on a per cell basis were about five times more active in provoking mitogenesis than cells treated with $\mathrm{C}$ alone. Therefore, total accessory function is not reduced by monocyte depletion, and specific activity may be increased when monocytes represent a large fraction of total mononuclear cells.

Since RA effusions contain activated $T$ cells and B lymphocytes, both of which display la antigens, stimulatory activity was also evaluated after elimination of both monocytes and

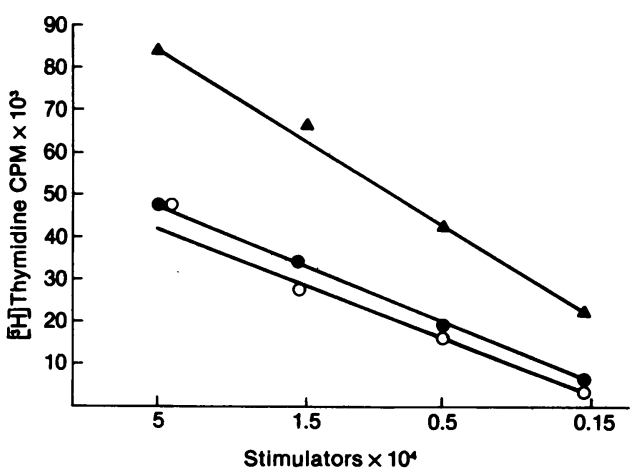

Figure 2. Similar to Fig. 1 except that nonadherent synovial cells were studied after $2 \mathrm{~d}$ of culture and were treated with $\mathrm{C}$ alone (o; $14 \%$ cell death), $3 \mathrm{Cl} 10 \alpha$-monocyte MAb (॰; 33\% killing), or a cocktail of $\alpha$-monocyte and B and T cell MAb ( $\Delta ; 90 \%$ killing). 

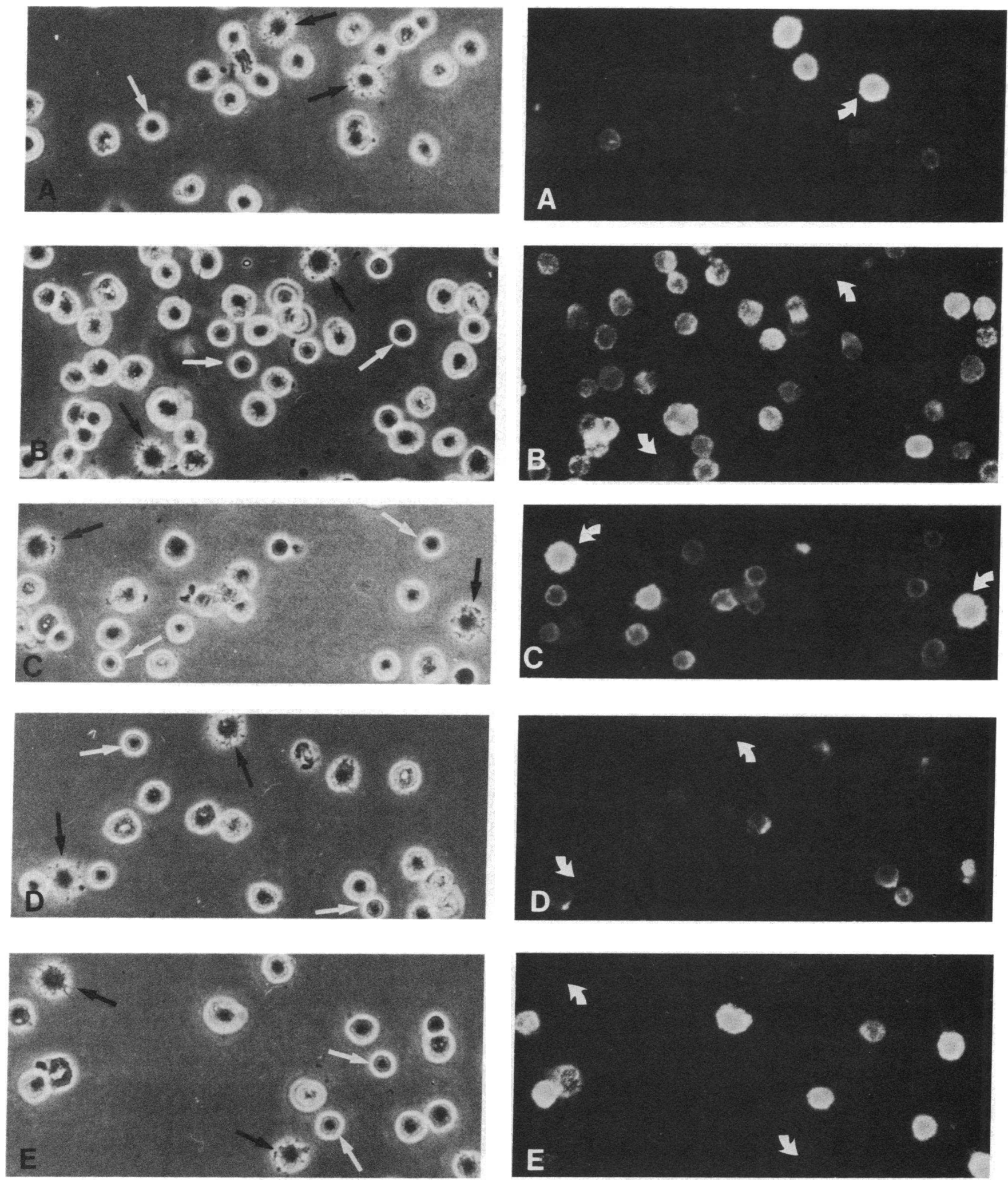

Figure 3. The phenotype of mononuclear cells in the plastic adherent fraction of synovial effusions. Cells were attached to glass slides and stained with MAb. The same field was photographed with phase contrast (left) and fluorescence (right) microscopy. Conditions for the exposure and development of the micrographs were similar. By phase contrast $(\times 625)$, each sample contained a major population of large round cells and minor populations of small round cells (lymphocytes, white arrows) and spiny cells (DC, black arrows). By immunofluorescence (right) the following occurred: $(A) 8 C 4$ stained DC brightly

(white arrowhead) and some small presumed B cells weakly. $(B)$ OKM1 ( $\alpha$-C3bi receptor) stained most synovial cells except for some of the lymphocytes. The DC (white arrowheads) showed weak reactivity. (C) 9.3F10 ( $\alpha$-HLA DR and DQ) stained most synovial cells, but the DC were especially bright (white arrowheads). $(D)$ BA-1 ( $\alpha$-B cell) did not stain DC (white arrowhead) but did react with a few round cells. $(E)$ 63D3 ( $\alpha$-monocyte) stained most large round cells but not the lymphocytes or DC (white arrowheads). Identical results were observed with $3 \mathrm{Cl}$, another $\alpha$-monocyte reagent. 
lymphocytes with an appropriate mixture of MAb. Although 85-95\% of the mononuclear cells were killed, the residual population retained stimulatory activity and on a per cell basis was 4-10-fold more active than the same cells treated with $\mathrm{C}$ alone (4 experiments). One such study is shown in Fig. 2, where it can be seen that there was a slight enhancement of stimulatory activity when monocytes (14\% of the mononuclear cells) were depleted, and a seven- to eightfold increase when both lymphocytes and monocytes were removed.

Identification of synovial fluid dendritic cells. Adherent synovial fluid cells were isolated after 1 or more $d$ in culture, attached to poly-L-lysine-coated slides, stained with MAb using a biotin-avidin technique, fixed, and examined. By phase contrast, the populations that were exposed to $C^{\prime}$ only (Fig. 3) consisted primarily of large round cells, most of which were phenotyped as monocytes (3C10, 63D3, OKM1, positive; BA1, 1F5, OKT3, T101, HL, 3G8, HNK1, Leu 7, negative). A few of the large cells were B cells (HL, BA-1, 1F5, positive) and NK cells (HNK1 and Leu 7, positive), and most of the small cells were $\mathrm{T}$ lymphocytes (OKT3, T101, T11, positive). In addition, there was a minor (1-5\%) population of spiny cells or DC that stained strongly with $\alpha$-Ia (both DR and DQ), weakly with OKM1 ( $\alpha$-C3bi receptor), but lacked monocyte, B, T, and NK antigens as well as Fc receptors (e.g., Fig. 3). The weak OKM1 staining of candidate DC was confirmed on blood DC. In earlier studies (23), this weak stain was not appreciated because the lot of OKM1 that was available did not react as strongly with monocytes as the current lot. Most of the synovial fluid cells stained with $\alpha$-DR antibodies, but the DC were stained the strongest (Fig. 3). The $\alpha$-DQ reagent, Leu 10, stained DC strongly and presumed B cells weakly.

When similar experiments were performed on populations that had been treated with $3 \mathrm{C10}, \mathrm{BA}-1$ and T101 MAb ( $\alpha$-monocyte, B and T cell), and $\mathrm{C}^{\prime}$, the bulk of the surviving cells were dendritic in shape (Fig. 4). Their surface phenotype was $\mathrm{Ia}^{+}$and $4 \mathrm{~B}^{+}$(leukocyte common antigen) but negative for 63D3, 3C10, OKT3, 1F5, HNK, HL, and 3G8 antigens (e.g., Fig. 5). Neither control nor DC-enriched populations stained with the $\alpha$-Langerhans cell/thymocyte reagent, OKT6 (not shown).
A particularly interesting MAb was $8 \mathrm{C} 4$, which is a new reagent that has some similarities with $\alpha$-HLA DQ antibodies like Leu 10, in that it stains blood DC strongly, B cells weakly or moderately, and monocytes weakly if at all. 8C4 also stained the candidate DC in synovial effusions (Fig. 3) and most of the cells that survived lysis with $\alpha$-monocyte and lymphocyte MAb (Fig. 5). We conclude that there are DC in synovial effusions that express the same cell surface antigens as their counterparts in blood; namely, positive for DR, DQ, and leukocyte antigens and weakly positive for OKM1. In fact, synovial DC typically could not be distinguished from parallel samples of adherent blood DC except that the synovial cells could be larger in size.

Phagocytosis by synovial fluid mononuclear cells. Mononuclear cells that appeared to be monocytes by phase-contrast microscopy phagocytosed large numbers of latex particles, whereas small round (T) and dendritic cells did not (Fig. $6 A$ ). The phagocytes were verified to be monocytes by virtue of staining with the cell-specific MAb, 63D3 (Fig. $6 \mathrm{~B}$ ). The nonphagocytic DC did not stain with 63D3 (Fig. $6 \mathrm{~B}$ ) but did stain with the $8 \mathrm{C} 4 \mathrm{MAb}$ (not shown).

Electron microscopy. Four samples of synovial fluid mononuclear cells, obtained after 1-3 d of culture, were examined by transmission electron microscopy with or without enrichment for DC. The control populations were comprised primarily of typical macrophages and lymphocytes. The macrophages contained many large endocytic vacuoles filled with debris (arrows, Fig. 7). In contrast, most of the cells in the DCenriched fraction (verified to be depleted of monocytes and lymphocytes by immunofluorescent staining) resembled blood DC with the exception that the cytoplasm contained large numbers of organelles (Fig. 8). The nuclei were large and irregularly shaped and had a peripheral rim of heterochromatin and small nucleoli. There were many mitochondria with associated profiles of rough endoplasmic reticulum. Lysosomes were few to moderate in number, pinocytic vesicles were infrequent, and the Golgi saccules were few and short. Birbeck granules were not found.

Several distinctive features of synovial fluid DC were best appreciated at higher magnification (Fig. 9). One was a well-

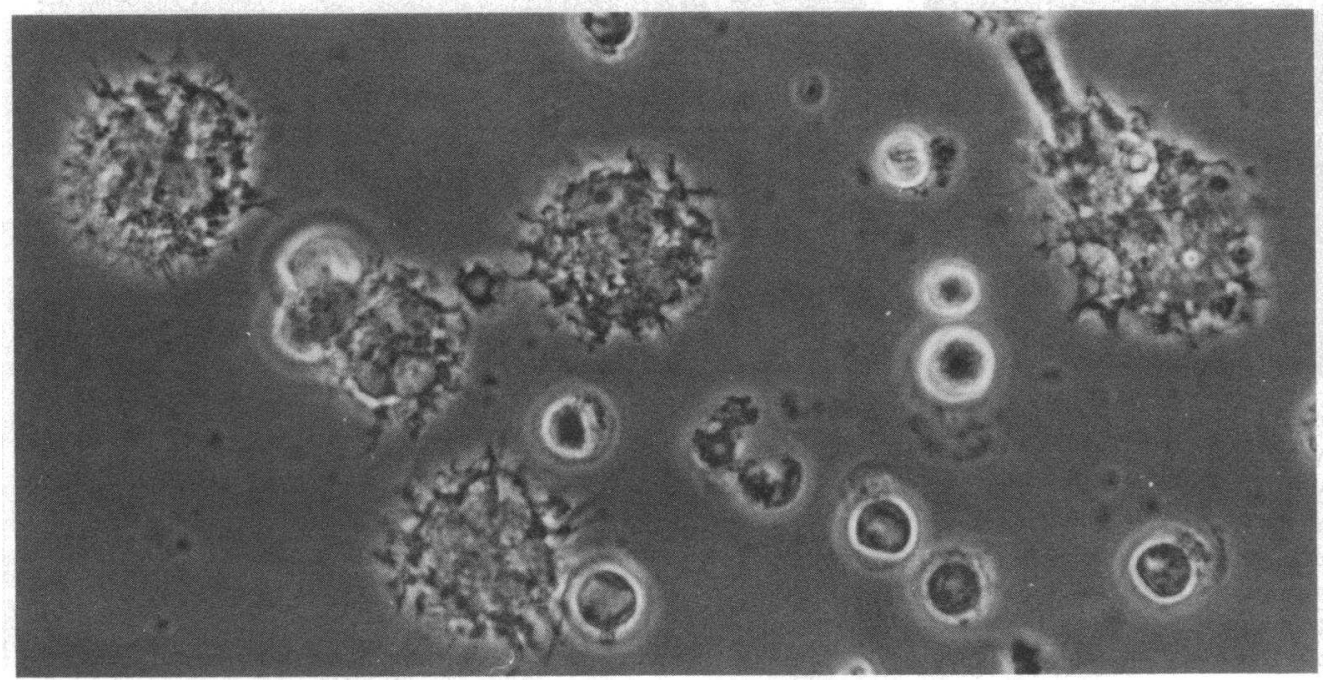

Figure 4. The dendritic appearance of the majority of viable synovial cells surviving treatment with $\alpha$-monocyte and $\alpha$-lymphocyte MAb and C. Most of the small round profiles are nuclei of the lysed cells. $(\times 1,000$. 

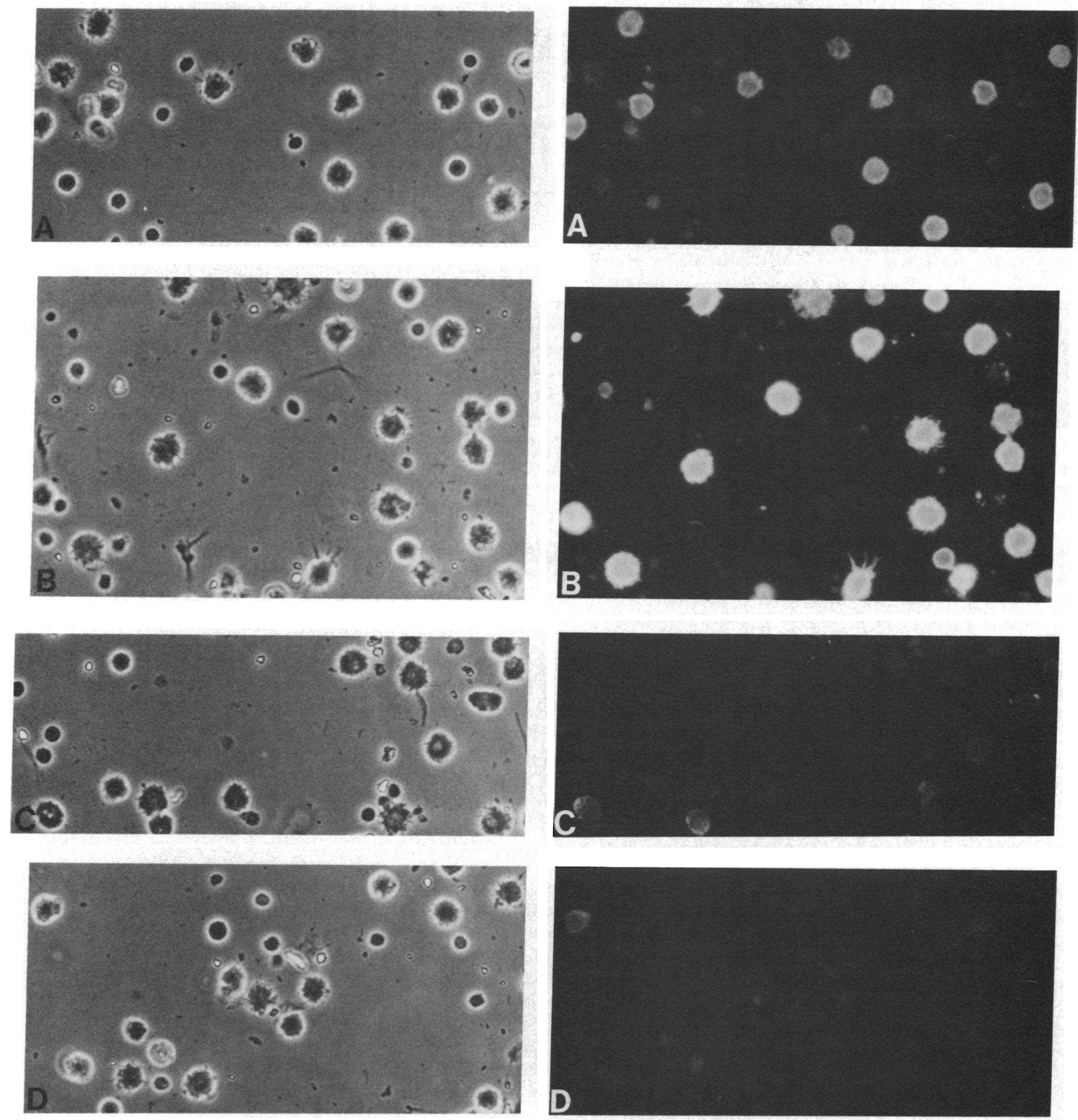

Figure 5. Enrichment of synovial DC from cultured (2 d) nonadherent populations by depletion of monocytes and lymphocytes. Under phase contrast (left), most of the profiles are irregularly shaped DC while smaller profiles are dead cells. By immunofluorescence (right), the DC are $8 \mathrm{C}^{+}(A), 9.3 \mathrm{~F} 10$ or $\mathrm{Ia}^{+}(B), \mathrm{HNK}-1^{-}(C)$, and hairy cell/B lymphoblast negative $(D)$.

developed smooth reticulum consisting of short tubular profiles with an electron-dense content. The profiles were especially frequent in the perinuclear zone and resembled comparable structures in interdigitating cells $(39,40)$, the presumed in situ counterparts of DC in sections of lymphoid organs. Another feature that was not seen in synovial monocytes and lymphocytes were large bundles of intermediate filaments that frequently swept around the nucleus. The DC surface was dis- tinctive, being covered with blunt processes of varying length. The processes contained a fine matrix that excluded organelles. Coated pits and vesicles were not observed.

\section{Discussion}

The joint effusions from patients with RA contain cells that are similar to the DC in human blood $(20,23,24)$ and in 

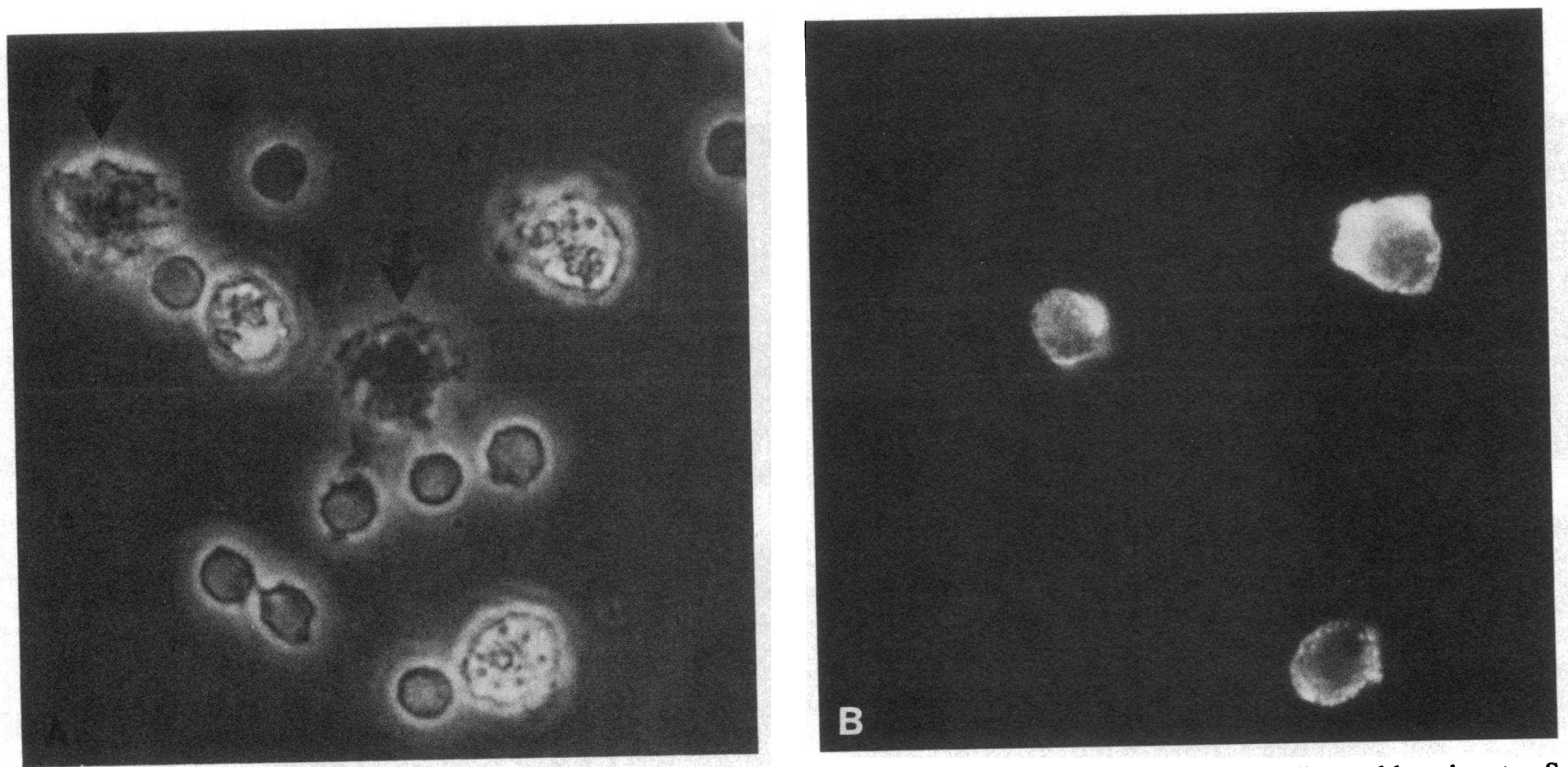

Figure 6. Latex phagocytosis by monocytes from synovial effusions. By phase contrast $(A)$, most of the cells are small round lymphocytes. Some of the larger cells have phagocytosed the refractile latex particles and are monocytes, since they stained with 63D3 $\alpha$-monocyte MAb (B). Two DC (black arrows) are nonphagocytic and $63 \mathrm{D}^{-} .(\times 1,000$.

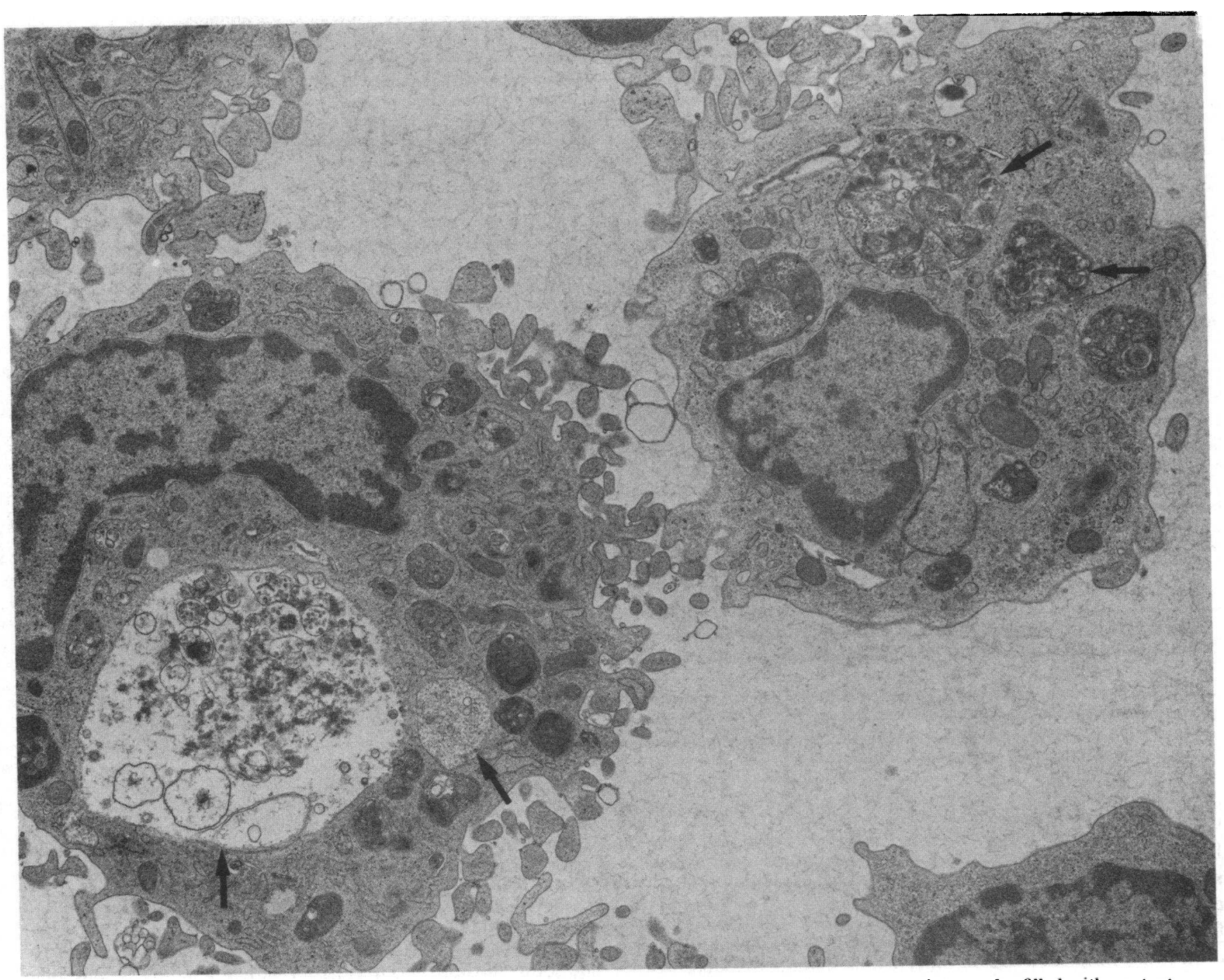

Figure 7. Electron micrograph (low power) of two synovial fluid macrophages to illustrate the many endocytic vacuoles filled with content (arrows). ( $\times 14,000$.) 


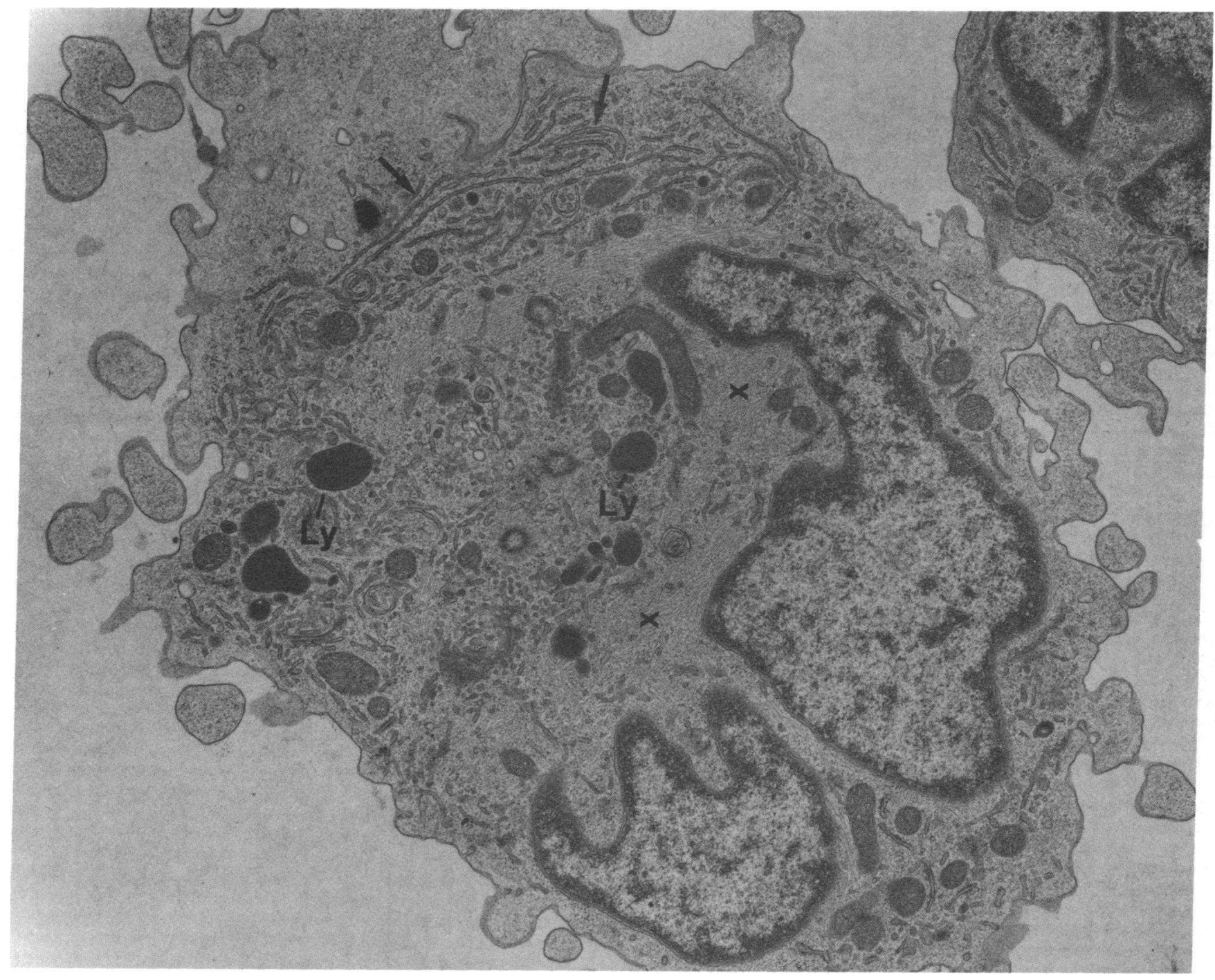

Figure 8. Electron micrograph (low power) of a synovial DC enriched by depleting lymphocytes and macrophages. The surface is covered with knoblike protrusions. The cytoplasm has many mitochondria and thick bundles of microfilaments $(x)$. The Golgi stacks are not prominent, but the Golgi region is filled with narrow, smooth, membrane-bound profiles and some lysosomes (Ly). Cisternae of rough endoplasmic reticulum are in the cell periphery (arrows). $(\times 17,000$.)

lymphoid organs of other species $(18,39,41)$. By phase contrast, we have noted a subpopulation of irregularly shaped mononuclear cells that had the same surface markers as DC in normal blood (Ia-rich; C3bi-receptor weak; monocyte, lymphocyte, and NK differentiation antigen negative; Fig. 3). When monocytes and lymphocytes were selectively eliminated, exudate DC were enriched, as evidenced by phase-contrast and surface markers (Figs. 4 and 5), by ultrastructure (Figs. 8 and 9), and by stimulatory function (Figs. 1 and 2, Table IV). Whereas the majority of freshly isolated blood DC stuck to plastic, synovial DC partitioned variably between adherent and nonadherent populations (Table III). Therefore we focused on cell depletion rather than adherence as an enrichment technique.

Other cell types in joint effusions and in the synovial lining could exhibit some features of DC. Synovial lining cells of RA patients, for instance, are rich in HLA-DR antigens (27-30). When synovial lining has been dispersed with proteolytic enzymes, a variable number adhere to the surface of the culture vessel and assume a distinctive stellate morphology (31). Such cells are many times larger than the adherent macrophages in the same culture and have dendritic processes that extend for long distances $(10-40 \mu \mathrm{M})$. A number of findings suggest that collagenase-producing, stellate, synovial cells are most likely related to fibroblasts (31) and include the observation that after several passages, a typical fibroblast morphology is assumed. The cells reassume the stellate form if endogenous prostaglandin $\mathrm{E}_{2}\left(\mathrm{PGE}_{2}\right)$ production is stimulated or if exogenous $\mathrm{PGE}_{2}$ is added (38). The studies of Burmester et al. and Winchester and Burmester show that a proportion of isolated synovial lining cells are nonphagocytic and do not stain with MAb to lymphocyte, monocyte, or fibroblast antigens $(27,32)$. This $\mathrm{DR}^{+}$population also assumes a stellate or dendritic appearance, but in contrast to synovial fluid DC, the former cells are larger and rapidly lose their long processes and surface Ia (31). Poulter et al. (29) have likened some of 


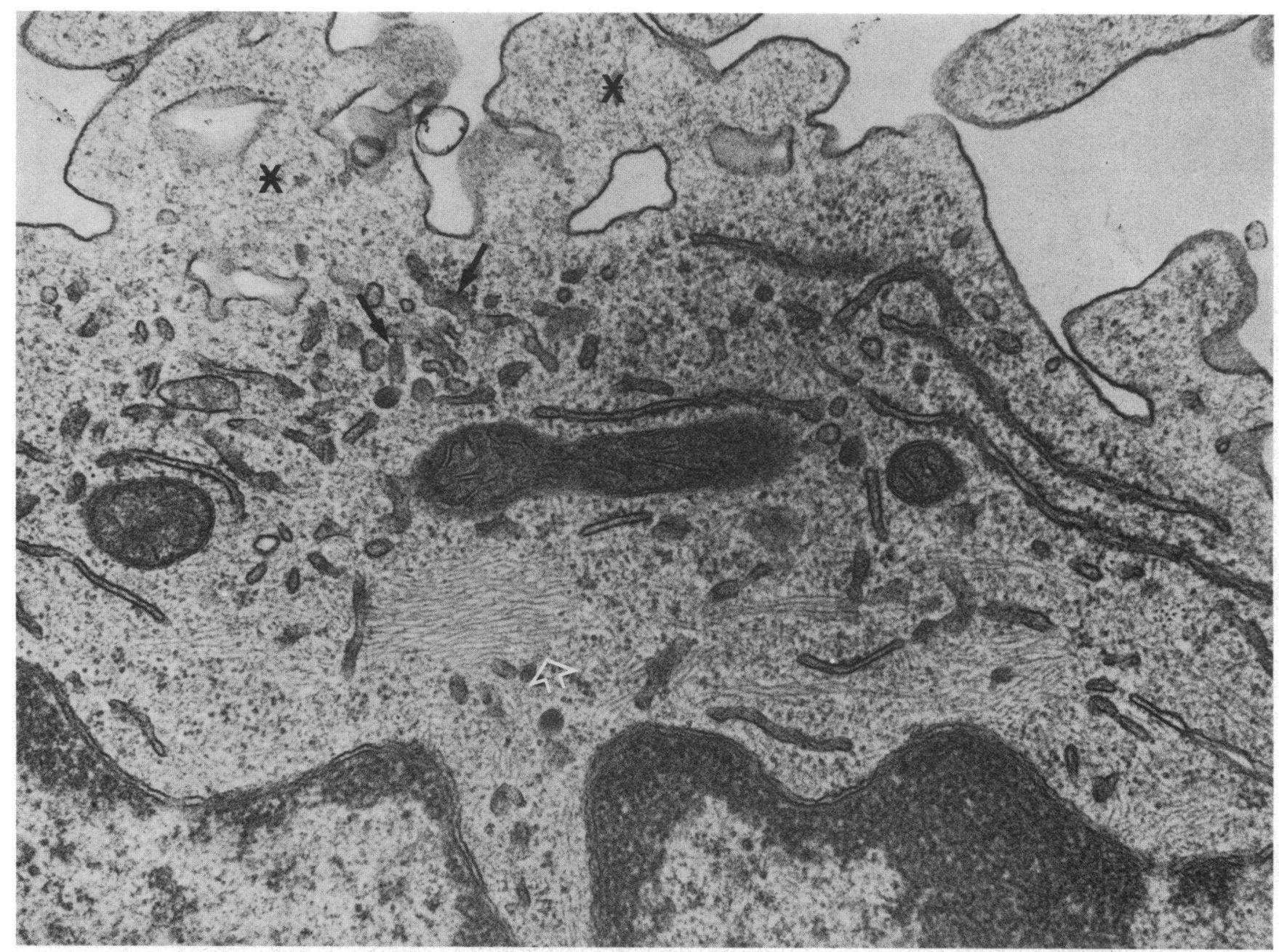

Figure 9. Electron micrograph (high power) of a synovial DC to illustrate smooth-surfaced tubular profiles with electron-dense content (arrows), surface processes that are filled with a fine fibrillar content $(*)$, and bundles of intermediate-sized filaments (arrowhead). $(\times 45,000$.)

the dendritic, DR-rich, non-T cells in the synovial membrane to the interdigitating cells of the $\mathrm{T}$ areas of lymphoid organs $(39,40)$. Some cells included in the heterogeneous population of adherent, DR-rich synoviocytes can stimulate an allogeneic $\operatorname{MLR}(28,42)$. Optimum stimulation has been observed with a concentration of adherent cells that is $1 / 20-1 / 100$ th that for blood non-T cells. Therefore it has been reasoned that the synovial membrane population contains an active stimulator cell as well as suppressor cells, possibly macrophages. In our study of exudate cells, elimination of macrophages occasionally produced a modest increase in total accessory function (Fig. 1), but the more typical observation was an increase in specific activity that was proportional to the enrichment for synovial fluid DC (Table IV, Fig. 2).

While blood DC appear to be the one cell with the same constellation of features as synovial DC, their frequencies differ, being $0.1-0.5 \%$ in blood (23) and $1-5 \%$ in synovial effusions. Given their functional capacities, the increased frequency of DC likely explains why synovial non-T cells are more active stimulators of $\mathrm{T}$ cell proliferation than blood non$T$ cells (8).

The mechanism for the accumulation of DC in joint fluid is not clear. Information about the life history and traffic patterns of DC is just beginning to emerge. DC originate from a precursor in bone marrow and are found in small numbers in blood. Sizable numbers of cells that resemble DC and are often termed "veiled cells" have been found in afferent but not efferent lymph $(25,43,44)$. Therefore, a pool of DC likely exists in nonlymphoid tissues and is capable of moving into afferent lymph. The best example would be the epidermal Langerhans cell, which is related to DC (45). It has been postulated that Langerhans cells move via the lymph to nodes to become the interdigitating or Ia-rich dendritic cells of $T$ dependent regions (44). Therefore one possibility is that synovial fluid DC are derived from cells that are normally present in the synovial lining, and that egress via the lymph is altered during arthritis leading to an accumulation or reflux into the synovial cavity. Tyndall et al. have likened some of the cells in synovial effusions to the veiled cells in lymph (46). An alternative is that synovial DC represent an influx from blood as part of the inflammatory process.

Regardless of mechanism, the presence of DC in an inflammatory site would be expected to intensify the local immune response. DC are active stimulators of several $\mathrm{T}$ - 
dependent responses including the syngeneic MLR, the release of lymphokines, the development of cytolytic $T$ cells, and the secretion of antibody to $T$-dependent antigens (16-20, 47, 48). DC are particularly specialized to initiate responses in resting helper $T$ cells, whereas other cell types like macrophages and B lymphocytes can interact with helper cells in the effector limb of immunity $(49,52)$. Therefore, it is tempting to propose that synovial DC contribute to the intraarticular activation of $T$ cells that has been described in RA. The experience with one patient with psoriatic arthritis (J.H., Table III) may indicate that increased numbers of synovial fluid DC will accompany other forms of chronic joint inflammation. Studies are in progress to address this point.

\section{Acknowledgments}

Some of the synovial fluids were provided by physicians from the Hospital for Special Surgery, New York, NY. The authors thank Judy Adams for help with electron microscopy, Van Tsai for performing the endocytosis studies, and Leslye Rucker for typing the manuscript.

This work was supported in part by National Institutes of Health grants AM-14916 and CA-30198 and by grants from the Kroc Foundation. Dr. Steinman is an established Investigator of the American Heart Association. Dr. Kaplan is a Heiser Fellow.

\section{References}

1. Zvaifler, N. J. 1983. Pathogenesis of the joint disease of rheumatoid arthritis. Am. J. Med. 75(Suppl.):3-8.

2. Duke, O., G. S. Panayi, and G. Janossy. 1983. Analysis of T cell subsets in the peripheral blood and synovial fluid of patients with rheumatoid arthritis by means of monoclonal antibodies. Ann. Rheum. Dis. 42:357-361.

3. Fox, R. I., S. Fong, N. Sabharwal, S. A. Carstens, P. C. Kung, and J. H. Vaughan. 1982. Synovial fluid lymphocytes differ from peripheral blood lymphocytes in patients with rheumatoid arthritis. $J$. Immunol. 128:351-354.

4. Galili, U., L. Rosenthal, N. Galili, and E. Klein. 1979. Activated $T$ cells in the synovial fluid of arthritic patients: characterization and comparison with in vitro activated human and murine $T$ cells in cooperation with monocytes in cytotoxicity. J. Immunol. 122:878883.

5. Galili, U., L. Rosenthal, and E. Klein. 1981. Activated T cells in the synovial fluid of arthritis patients. II. In vitro activation of the autologous blood lymphocytes. J. Immunol. 127:430-432.

6. Silver, R. M., D. Redelman, N. J. Zvaifler, and S. J. Naides. 1982. Studies of rheumatoid synovial fluid lymphocytes. I. Evidence for activated natural killer (NK)-like cells. J. Immunol. 128:17581763.

7. Goto, M., and N. J. Zvaifler. 1985. Characterization of the precursors of the NK-like cytotoxic cells generated in the autologous mixed leukocyte reaction and by interleukin 2 activation. J. Immunol. 134:1483-1486.

8. Hepburn, B., F. C. McDuffie, and R. E. Ritts, Jr. 1976. Impaired blastogenic response of lymphocytes from synovial fluid and peripheral blood of patients with rheumatoid arthritis. J. Rheumatol. 3:118-123.

9. Silverman, H. A., J. S. Johnson, J. H. Vaughan, and J. C. McGlamory. 1976. Altered lymphocyte reactivity in rheumatoid arthritis. Arthritis Rheum. 19:509-515.

10. Burmester, G. R., J. R. Kalden, H. H. Peter, I. Schedel, D. Beck, and A. Wittenborg. 1978. Immunological and functional characteristics of peripheral blood and synovial fluid lymphocytes from patients with rheumatoid arthritis. Scand. J. Immunol. 7:405-411.

11. Stratton, J. A., and J. B. Peter. 1978. The responses of peripheral blood and synovial fluid lymphocytes of patients with rheumatoid arthritis due to in vitro stimulation with mitogen. Clin. Immunol. Immunopathol. 10:233-241.

12. Corrigall, V., G. S. Panayi, and R. Laurent. 1979. Lymphocyte studies in rheumatoid arthritis. III. A comparative study of the responses of peripheral blood and synovial fluid lymphocytes to phytomitogen. Scand. J. Rheumatol. 8:10-16.

13. Silver, R. M., D. Redelman, and N. J. Zvaifler. 1983. Studies of rheumatoid synovial fluid lymphocytes. II. A comparison of their behavior with blood mononuclear cells in the autologous mixed lymphocyte reaction and response to TCGF. Clin. Immunol. Immunopathol. 27:15-27.

14. Crout, J. E., F. C. McDuffie, and R. E. Ritts, Jr. 1976. Induction of peripheral blood lymphocyte transformation by autologous synovial fluid lymphocytes and synovial fluid. Arthritis Rheum. 19:523-531.

15. Beck, P., G. R. Burmester, A. Ledwock, C. Urban, and J. R. Kalden. 1981. Autologous and allogeneic MLC-reactivity in patients with rheumatoid arthritis. J. Clin. Lab. Immunol. 6:27-33.

16. Steinman, R. M., B. Gutchinov, M. D. Witmer, and M. C. Nussenzweig. 1983. Dendritic cells are the principal stimulators of the primary mixed leukocyte reaction in mice. J. Exp. Med. 157:613-627.

17. Austyn, J. M., R. M. Steinman, D. E. Weinstein, A. GranelliPiperno, and M. A. Palladino. 1983. Dendritic cells initiate a two stage mechanism for lymphocyte proliferation. J. Exp. Med. 157:11011115.

18. Klinkert, W. E. F., J. H. LaBadie, and W. E. Bowers. 1982. Accessory and stimulating properties of dendritic cells and macrophages isolated from various rat tissues. J. Exp. Med. 156:1-19.

19. Van Voorhis, W. C., J. Valinsky, E. Hoffman, J. Luban, L. S. Hair, and R. M. Steinman. 1983. The relative efficacy of human monocytes and dendritic cells as accessory cells for $\mathrm{T}$ cell replication. J. Exp. Med. 158:174-191.

20. Kuntz-Crow, M., and H. G. Kunkel. 1982. Human dendritic cells: major stimulators of the autologous and allogeneic mixed leukocyte reactions. Clin. Exp. Immunol. 49:338-341.

21. Steinman, R. M., J. C. Adams, and Z. A. Cohn. 1973. Identification of a novel cell type in peripheral lymphoid organs of mice. I. Morphology, quantitation, tissue distribution. J. Exp. Med. 137:1142-1162.

22. Nussenzweig, M. C., R. M. Steinman, J. C. Unkeless, M. D. Witmer, B. Gutchinov, and Z. A. Cohn. 1981. Studies of the cell surface of mouse dendritic cells and other leukocytes. J. Exp. Med. 154:168-187.

23. Van Voorhis, W. C., L. S. Hair, R. M. Steinman, and G. Kaplan. 1982. Human dendritic cells: enrichment and characterization from peripheral blood. J. Exp. Med. 155:1172-1187.

24. Van Voorhis, W. C., R. M. Steinman, L. S. Hair, J. Luban, M. D. Witmer, S. Koide, and Z. A. Cohn. 1983. Specific antimononuclear phagocyte monoclonal antibodies: application to the purification of dendritic cells and the tissue localization of macrophages. J. Exp. Med. 158:126-145.

25. Pugh, C. W., G. G. MacPherson, and H. W. Steer. 1983. Characterization of non-lymphoid cells derived from rat peripheral lymph. J. Exp. Med. 157:1758-1779.

26. Nussenzweig, M. C., R. M. Steinman, M. D. Witmer, and B. Gutchinov. 1982. A monoclonal antibody specific for mouse dendritic cells. Proc. Natl. Acad. Sci. USA. 79:161-165.

27. Burmester, G. R., F. Dimitru-Bona, S. J. Waters, and R. J. Winchester. 1983. Identification of three major synovial lining cell populations by monoclonal antibodies directed to Ia antigens and antigens associated with monocytes/macrophages and fibroblasts. Scand. J. Immunol. 167:69-82.

28. Klareskog, L., U. Forsum, D. Kabelitz, L. Ploen, C. Sundstrom, K. Nisson, A. Wigren, and H. Wigzell. 1982. Immune functions of human synovial cells. Phenotypic and T cell regulatory properties of macrophage-like cells that express HLA-DR. Arthritis Rheum. 25:488501.

29. Poulter, L. W., O. Duke, S. Hobbs, G. Janossy, G. Panayi, and 
G. Seymour. 1983. The involvement of interdigitating cells in the pathogenesis of rheumatoid arthritis. Clin. Exp. Immunol. 51:247254.

30. Young, C. L., T. Adamson, J. H. Vaughan, and R. I. Fox. 1984. Immunohistologic characterization of synovial membrane lymphocytes in rheumatoid arthritis. Arthritis Rheum. 27:32-39.

31. Amento, E. P., A. K. Bhan, K. G. McCullagh, and S. M. Krane. 1985. Influence of gamma interferon on synovial fibroblastlike cells. Ia induction and inhibition of collagen synthesis. J. Clin. Invest. In press.

32. Winchester, R. J., and G. R. Burmester. 1981. Demonstration of Ia antigens on certain dendritic cells and on a novel elongate cell found in human synovial tissues. Scand. J. Immunol. 14:439-444.

33. Woolley, D. E., C. E. Brinckerhoff, C. L. Mainardi, C. A Vater, J. M. Evanson, and E. D. Harris, Jr. 1979. Collagenase production by rheumatoid synovial cells: morphological and immunohistochemical studies of the dendritic cell. Ann. Rheum. Dis. 38 : 262-270.

34. Ropes, M. W., E. A. Bennett, S. Cobbs, R. Jacox, and R. Jessar. 1958. Revision of diagnostic criteria for rheumatoid arthritis Bull. Rheum. Dis. 9:175-177.

35. Posnett, D. N., N. Chiorazzi, and H. G. Kunkel. 1982. Monoclonal antibodies with specificity for hairy cell leukemia cells. $J$. Clin. Invest. 70:254-261.

36. Novogrodsky, A., and E. Katchalski. 1971. Induction of lymphocyte transformation by periodate. FEBS (Fed. Eur. Biochem. Soc.) Lett. XII:297-302.

37. Beyer, C. F., and W. E. Bowers. 1978. Lymphocyte transformation induced by chemical modification of membrane components. II. Effect of neuraminidase treatment of responder cells on proliferation and cytotoxicity in indirect stimulation. J. Immunol. 121:1790-1798.

38. Baker, D. G., J. M. Dayer, M. Roelke, H. R. Schumacher, and S. M. Krane. 1983. Rheumatoid synovial cell morphologic changes induced by a mononuclear cell factor in culture. Arthritis Rheum. 26 8-14.

39. Veldman, J. E., and E. Kaiserling. 1980. Interdigitating cells In The Reticuloendothelial System, Morphology. Vol. 1. I. Carr and W. T. Daems, editors. Plenum Publishing Corp., New York. 381-416.

40. Heusermann, U., H. J. Stutte, and H. K. Můller-Hermelink. 1974. Interdigitating cells in the white pulp of the human spleen. Cell Tissue Res. 153:415-417.
41. Van Voorhis, W. C., M. D. Witmer, and R. M. Steinman 1984. The phenotype of dendritic cells and macrophages. Fed. Proc 42:70-73.

42. Klareskog, L., U. Forsum, A. Scheynius, D. Kabelitz, and H. Wigzell. 1982. Evidence in support of a self-perpetrating HLA-DRdependent delayed-type cell reaction in rheumatoid arthritis. Proc. Natl. Acad. Sci. USA. 79:3632-3636.

43. Kelly, R. H., B. M. Balfour, J. A. Armstrong, and S. Griffiths. 1978. Functional anatomy of lymph nodes. II. Peripheral lymph borne mononuclear cells. Anat. Rec. 190:5-21.

44. Drexhage, H. A., H. Mullink, J. de Groot, J. Clarke, and B. M. Balfour. 1979. A study of cells present in peripheral lymph of pigs with special reference to a type of cell resembling the Langerhans cells. Cell Tissue Res. 202:407-430.

45. Schuler, G., and R. M. Steinman. 1985. Murine epidermal Langerhans cells mature into potent immunostimulatory cells in vitro. J. Exp. Med. 161:526-546.

46. Tyndall, A. D., S. C. Knight, A. J. Edwards, and J. B. Clarke. 1983. Veiled (dendritic) cells and synovial fluid. Lancet. I:472-473.

47. Inaba, K., R. M. Steinman, W. C. Van Voorhis, and S. Muramatsu. 1983. Dendritic cells are critical accessory cells for thymusdependent antibody responses in mouse and man. Proc. Natl. Acad. Sci. USA. 80:6041-6045.

48. Inaba, K., A. Granelli-Piperno, and R. M. Steinman. 1983. Dendritic cells induce $T$ lymphocytes to release B cell stimulatory factors by an interleukin 2-dependent mechanism. J. Exp. Med. 158: 2040-2057.

49. Inaba, K., and R. M. Steinman. 1984. Resting and sensitized T lymphocytes exhibit distinct stimulatory (antigen presenting cell) requirements for growth and lymphokine release. J. Exp. Med. 160: 1717-1735.

50. Clarke, E. A., G. Shu, and J. A. Ledbetter. 1985. Role of the Bp35 cell surface polypeptide in human B cell-activation. Proc. Natl. Acad. Sci. USA. 82:1766-1770.

51. Fleit, H. B., S. D. Wright, and J. C. Unkeless. 1982. Human neutrophil $\mathrm{Fc}_{\gamma}$ receptor distribution and structure. Proc. Natl. Acad. Sci. USA. 79:3275-3279.

52. Inaba, K., and R. M. Steinman. 1985. Protein-specific helper T lymphocyte formation initiated by dendritic cells. Science (Wash. $D C$ ). In press. 